\title{
LAMA3 wt Allele
}

National Cancer Institute

\section{Source}

National Cancer Institute. LAMA3 wt Allele. NCI Thesaurus. Code C137976.

Human LAMA3 wild-type allele is located in the vicinity of $18 q 11.2$ and is approximately $266 \mathrm{~kb}$ in length. This allele, which encodes laminin subunit alpha-3 protein, plays a role in cell-matrix attachment. 